\title{
A sustainability assessment of the Hostětín cider house project
}

\author{
Jan Labohý, Yvonna Gaillyová, Radim Machů \\ Envigogika 10 (1) - Reviewed Papers/ Recenzované články
}

Published/ Publikováno 14. 3. 2015

DOI: $10.14712 / 18023061.449$

\begin{abstract}
The article presents and assesses the Hostětín cider house - a sustainability-oriented local economy project in the Czech Republic. The project is described in detail: its origin, development and operation, funding, and relationships with involved actors. A background in the sustainability indicator science and a comprehensive description of the project have enabled the authors to propose complex indicators to assess the sustainability of the project in relation to different kinds of capital according to Meadows. Sustainability characteristics are outlined with regards to the technology used, including energy resources, the apples used in the production process (which represent local cultural heritage), products and waste. Effects on the local economy are measured using the local multiplier effect indicator. The assessment suggests that the initial goals of the cider house project have been met and that the project supports sustainable development.
\end{abstract}

\section{Keywords}

sustainability assessment, cider house, rural development, sustainable development, local economy

\begin{abstract}
Abstrakt
Článek představuje a hodnotí Hostětínskou moštárnu - projekt zaměřený na udržitelný rozvoj místní ekonomiky $\mathrm{v}$ podmínkách České republiky. Tento projekt je podrobně popsán: jeho vznik, postupné rozvíjení, zdroje financování, vztahy s dotčenými aktéry. Na základě poznatků vědy udržitelnosti a podrobného popisu samotného projektu navrhli autoři komplexní indikátory k hodnocení projektu ve vztahu k různým typům kapitálu dle Meadowse. Povaha udržitelnosti je pak hodnocena $s$ ohledem na použité technologie, včetně využívaných zdrojů energie, suroviny $v$ procesu výroby ( $v$ tomto prípadě jablka, jejichž odrůdy jsou místním kulturním dědictvím), konečné výrobky a odpady. Vliv na místní ekonomiku je měřen pomocí indikátoru "lokální multiplikátor". Hodnocená naznačuje, že původní cíle projektu moštárny byly naplněny a projekt tak podporuje udržitelný rozvoj na místní úrovni.
\end{abstract}




\section{Klíčová slova}

hodnocení udržitelnosti, moštárna, rozvoj venkova, udržitelný rozvoj, místní ekonomika 


\section{I ntroduction}

Although the UN Environmental and Development conferences in Johannesburg (2002) and Rio de Janeiro (2012) stated that the world as such is not moving significantly forward towards sustainable development, there has been significant action at the local level (Lafferty and Eckerberg, 2013). Sustainable rural livelihoods are expected to provide a range of functions central to sustainable development and their transition towards sustainable development is therefore crucial for the whole system (Elliott, 2006).

Sustainable rural development projects in Hostětín, the Czech Republic, are used as examples of best practice when formulating regional strategies and programmes of support to sustainable regional development, including programming documents of the operational programmes funded by the European Union. For the purpose of this article, although a sustainability assessment has not demonstrated impacts of the projects yet, we chose the cider house project with the goal of supporting the preservation of traditional fruit-growing in the White Carpathians by means of fruit processing and product marketing.

The aim of this article is to make a sustainability assessment of the Hostětín cider house project. Regarding the structure, the background of the project is described in its local and historical context in the beginning. By establishing the concept of sustainable development indicators, the article formulates community sustainability indicators for the project. Outcomes of the assessment are listed in the Results section, followed by discussion and conclusions.

\section{Hostětín and its historical context}

Projects dealing with the utilisation of local resources, energy savings, renewable energy sources and environmentally friendly technologies have been developed in the small White Carpathian village of Hostětín since the early 1990s. They have included a reed bed sewage treatment plant (completed in 1996), the use of solar technologies for hot water preparation and electricity production (1997-2011), heating for almost the whole village using wood chips (commissioned in 2000), energy-saving street lamps (2007), a cider house with organic production (in operation since 2000), the passive house of the Veronica Hostětín Centre (built in 2006), a demonstration natural garden together with an orchard with old local varieties (2013), and numerous educational elements accompanying these projects (Labohý, 2013).

The model projects in Hostětín did not originate from any external impulse. They are the result of a search for a balanced solution that conforms to local conditions. The village with a population of 250, whose continued existence was threatened by a ban on construction from the 1970s, was looking for the most appropriate wastewater treatment method. A combination of the nature protection needs in a Protected Landscape Area, persistent efforts of the mayor and the district authority, and expert and awareness-raising activities of the civic sector resulted in the construction of a reed bed treatment plant. Subsequently, it brought a lift of the construction ban, necessary for continued existence of the settlement, along with an innovative impulse which stimulated further development of the village in line with sustainable development principles (Uhlírová, 2008).

Among other factors, the common denominator of all the projects implemented afterwards was the co-operation between the municipal authority and the non-profit sector, making use of experience primarily from abroad. Ultimately, the comprehensive set of projects in Hostětín has helped to explore what future sustainable rural settlements might look like. The goal is a community that is on the path towards energy self-reliance, with a strong and functioning local economy that does not burden the environment (Labohý, 2013). 


\section{Hostětín cider house}

Besides orchid meadows and primeval fir-and-beech forest, extensive fruit orchards are one of the typical elements of the White Carpathian cultural landscape. The initial intention of voluntary nature conservationists (Czech Union for Nature Conservation, ČSOP ${ }^{1}$ ) to preserve the traditional fruit-growing in the White Carpathians has grown into a longterm programme of surveying and mapping the local gene pool, planting of gene pool orchards, and promotion of processing of the local fruit production. The construction of the cider house then became one of the progressive steps in the broadly designed fruit-growing programme for the White Carpathians (Tetera, 2006).

The initial plan was elaborated in a cooperation of several non-governmental organisations and local organic farmers. Together, they established the Tradice Bílých Karpat (White Carpathian Traditions, TBK) umbrella civic association in 1998. Its objective is to stimulate local inhabitants to manage the natural resources, landscape and biodiversity of the White Carpathians sustainably. Non-governmental organisations played the key role in the process: Veronica Ecological Institute (part of the ČSOP local group Veronica) and, later also the Veronica Foundation, which formulated a vision supposed to motivate local land owners to maintain and develop their orchards by means of processing, sales and utilisation of traditional fruit varieties (Uhlírová, 2008).

Another crucial factor for the establishment of the cider house was the long-term unique international co-operation of NGOs - the Veronica ČSOP local group and the Luxembourgish foundation Hëllef fir d'Natur - established in the period of both-sided efforts and enthusiasm in the civic sector after 1989. One of the central aspects was a great interest in experience transfer and adaption of innovative attitudes to environmental protection known abroad to Czech conditions. NGOs formulated the project aim as: "Support to preservation of traditional fruit-growing in the White Carpathians by means of fruit processing and product marketing" (Uhlírová, 2008).

The TBK decided to establish a cider house in Hostětín, in a property owned by the Veronica Foundation. It was an older farmstead with an orchard, bought in 1998. The renovation of the barn, designed to be the main production area of the future cider house, started in June 1999. The construction works were taken up by a group of local artisans, and volunteers and attendees of multiple-day summer courses and the international workshops of the INEX Association for Voluntary Activities took part in the auxiliary works during the summer breaks (Uhlířová, 2008).

\section{Sustainable development indicators}

Coming back to the history of sustainable development, the original definition comes from the World Conference on Environment and Development's report "Our Common Future" (Brundtland et al., 1987), often called the "Brundtland Report". The report defined sustainable development as: "Development that meets the needs of the present without compromising the ability of future generations to meet their own needs" (ibid.: 43). This definition was, however, very wide and more conceptualisation of the term was needed.

${ }^{1}$ The Czech Union for Nature Conservation is a part of the International Union for Conservation of Nature (IUCN). 
In 1992, the United Nations Conference on Environment and Development in Rio de Janeiro, Brazil, produced the first sustainable development action plan, called Agenda 21 (Agenda 21, 1993). For the first time, it offered a practical approach to applying sustainable development policies at both local and national levels. Chapter 28 invites each community to formulate its own Local Agenda 21: "Each local authority should enter into a dialog with its citizens, local organisations, and private enterprises and adopt 'a local Agenda 21'. Through consultation and consensus-building, local authorities would learn from citizens and from local, civic, community, business and industrial organisations and acquire the information needed for formulating the best strategies." (Agenda 21, 1993: Chapter 28, sections $1,3$. )

To be able to see actual change, specific sustainability goals must be set and subsequently assessed. In the late 1990s, sustainability assessment became a rapidly developing area, creating a whole new discipline within the sustainability science (Ness et al., 2007). The purpose of sustainability assessment, as proposed by Kates (2001), is to provide an evaluation of global to local integrated nature-systems in short-term and longterm perspectives in order to determine which actions should or should not be taken into account in an attempt to make society sustainable.

The method itself uses assessment tools - indicators - inspired by those used in biology. As Bell and Morse state, "Given that indicators have been widely employed by biologists for many years to gauge ecosystem health, it is not surprising that indicators (and indices, which are amalgams of indicators) have been seen by many as the core element in operationalising sustainability." (Bell and Morse, 2008: 27)

Thereafter, a whole range of sustainable development indicators (SDI) has been developed. Among others, Harger and Meyer (1996) set out the following characteristics that should be intrinsic to all SDIs: simplicity, diversity of issues, quantification, assessment of trends, sensitivity to change, and timeliness of trends.

Since the 1990s, many indicators have been developed and assessed (Singh et al., 2009; Mascarenhas et al., 2010; Pohekar and Ramachandran, 2004; Bell and Morse, 2008). However, as stated by Meadows, "It's easy enough to list the characteristics of ideal indicators. It's not so easy to find indicators that actually meet their ideal characteristics." (Meadows, 1998: viii)

The debate on sustainability indicators in the Czech Republic started with the Report on the State of the Environment in 1993 (Zpráva, 1994). Using the inspiration of the OECD methodology (OECD, 1993), the Report defined the core indicators of sustainable development for the Czech Republic. Thereafter, the Charles University Environment Centre has been developing and publishing sustainability indicators (Moldan, 1996; Moldan et al., 2002; Hák and Kovanda, 2006), resulting in current research in the field of material flows (Kovanda et al., 2008) and social metabolism (Weinzettel and Kovanda, 2009).

The European Common Indicators $(\mathrm{ECl})$, developed by the European Commission (Tarzia, 2003) are in use by some of the municipalities and NGOs. However, the set of indicators proposed by the Local Agenda 21 (Agenda 21, 1993) has been promoted by the Ministry of the Environment as well as the Healthy Cities ${ }^{2}$ organisation (Maštálka, 2009) and is therefore the most common at the municipality level. At the national level, sustainability

\footnotetext{
${ }^{2}$ An association of more than 100 cities, towns, municipalities, micro regions and regions inspired by the WHO Healthy Cities Project.
} 
has been measured by the indicators of the Progress Reports to the Sustainable Development Strategy of the Czech Republic (Kovanda et al., 2013). There is a methodology available to measure sustainability of enterprises (Študent et al., 2005); however, the set of indicators is more useful for medium-sized enterprises than for smaller ones.

Due to different contexts, environments, economies and societies, it is not really possible to develop universal indicators of sustainable development. Quoting Bell and Morse, "... the approach to measurement is always based on an individual's vision of sustainability, which in turn can be changed depending upon the measurement mindset." (Bell and Morse, 2008: xviii) Therefore, each community should develop its own community sustainability indicators that fit the purposes of the assessment and its goals (Valentin and Spangenberg, 2000).

We used this advice to develop specific indicators based on the project aims and the specific environment of the Hostětín cider house project. The methodology and indicators are described in the next section.

\section{Materials and methods}

To date, various methods have been developed and introduced to assess sustainability (Singh et al., 2009). Most of the methods are grounded in the basic distinction of sustainability into a system of "pillars", which highlights the most important dimensions of the term for specific authors. The original Brundtland system (Brundtland, 1987) is built on two pillars - environmental and developmental. The triple bottom line concept that has been the most popular within the sustainability science uses the environmental pillar, but separates developmental issues into two parts: social and economic (Pope et al., 2004). Some authors use the concept of different types of capital instead. Constanza and Daly (1992) use natural, human and manufactured capital as a background for sustainability; Goodwin (2003) defines financial, natural, produced, human and social capital. For the purpose of this article, the Meadows concept (Meadows et al., 1998) of capital types was chosen due to the best match with the project design, philosophy and the data that have been collected since its beginning.

Meadows et al. (1998) describe four different kinds of capital: natural capital, built capital, human capital, and social capital, and propose indicators to assess each of these categories.

Natural capital consists of the stocks and flows in nature from which human economy takes its materials and energy (sources) and into which we discard those materials and energy when we are done with them (sinks). Natural capital is used unsustainably if resources are declining or sinks are increasing (Meadows et al., 1998: 47-49). Therefore, we will explore the resources that are used by the cider house, its sources of energy, especially the proportion of renewable and non-renewable energy sources. We will look at the effects of the project on the landscape, and the waste management of the facility will be assessed as well.

Built capital is defined as a human-built, long-lasting physical capacity - factories, tools, machines - that produces economic output. Sustainability at the level of built capital means investing in an enterprise at least as fast as capital depreciates (Meadows et al., 1998: 53-54). Therefore, we will explore the initial funding, its sources and impacts. We will assess the current technologies used and the economic results of the enterprise. 
Human and social capital is understood as stocks of attributes (knowledge, trust, efficiency, honesty, information, intensity of human relations, etc.) that inheres within a single individual (human capital) or society (social capital) (Meadows et al., 1998). We will measure human and social capital using the opinions of local inhabitants and their mindset towards the local sustainable projects. We will measure the project's contribution to the local employability by accounting the number of local people employed by the project, and we will measure the impact on the local economy using the local multiplier effect and distancebased cumulated costs described below.

\section{Local multiplier effect}

We would like to describe one of the indicators in more detail: the local multiplier effect (LM3) indicator as proposed by Sacks (2002) and Kutáček (2007). This tool has been developed by the London-based New Economics Foundation (NEF) for measuring cash flows in a region. The idea is based on Keynes' original concept of national economies, i.e., the effect of governmental spending. In the modified version, the indicator makes it possible to track the role of a small organisation, enterprise or municipality in a local economy. The LM3 calculation first identifies a subject's total expenditures "a". In the next round, it calculates how much money would be expended locally (i.e., how much money would be paid to local suppliers and employers in a defined region) - this is " $b$ ". The third round then tracks how much of the locally expended money is spent locally as well (i.e., how much money the local suppliers and employers paid by the subject have spent locally) - this is "c". The resulting value of the indicator equals the quotient of the sum of the calculated local expenditures in all the three rounds divided by the expenditures in the first round; thus $(a+b+c) / a$. We use the LM2 indicator instead in cases where there are no data available for the third round of expenditures; thus LM2 equals $(a+b) / a$.

The local multiplier effect offers not an exact value but rather information about the circulation of money. However, this simple indicator enables us to acquire an insight into a much more complex issue: the functioning of a local economy.

\section{Distance-based cumulated costs}

In order to determine the current trends and proportion of local costs in the cider house economy, we quote so-called distance-based cumulated costs (Uhlířová, 2008). For each cost item/supplier, we calculate the geodesic distance from Hostětín based on the company's registered address, rank them in an ascending order based on the distance, and calculate the cumulated costs.

To sum up, we will put an emphasis on following indicators:

a) Natural capital

Indicators:

- Resources

- Share of renewable energy in total natural resources used

- Landscape management

- Waste management

b) Built capital

Indicators:

- Funding

- Used technology and investments

- Economic results 
c) Human and social capital

Indicators:

- Opinion of local inhabitants

- Employability

- Support to local economy measured by the local multiplier effect and distance-based cumulated costs

\section{Materials}

Materials for the research were collected in two rounds. The basic knowledge comes from the data collected and published in the Overall Assessments of the Hostětín projects (Uhlířová, 2008; Labohý, 2013). The rest of the data, especially in the Results section, come from individual archives, internal documents and data and memories of Yvonna Gaily, the chief executive of the NGO Veronica that came with the original idea of the cider house project, and Radim Machü, the company director of the cider house and a key person of the TBK civic association.

\section{Results}

\section{Natural capital}

\section{Resources}

The cider house buys most of the apples from organic farmers in the White Carpathians. The cider house has long-term co-operation with these suppliers. Apples from certified organic farming are the basis for all the BIO (Organic) labelled production. Apples brought to the cider house by local growers from Hostětín and its close vicinity in small quantities - tens to hundreds of kilograms - are a very interesting segment of the purchases. The fruit comes mostly from old varieties in small orchards and gardens, which cannot be certified as organic production for formal reasons. This fruit is processed into cider that, obviously, is not labelled as BIO (Figure 1). The emphasis on the regional origin of the product is clearly reflected in the structure of the apple suppliers for the cider house. An analysis of the apple purchase costs for 2004-2012 clearly indicates that more than $86 \%$ of the costs of apple purchases were expended within $40 \mathrm{~km}$ of Hostětín. At the same time, a significant portion of the suppliers grow their apples within the White Carpathians Protected Landscape Area. The apple purchases make up approx. $21 \%$ of the total cider house costs (Labohý, 2013). 


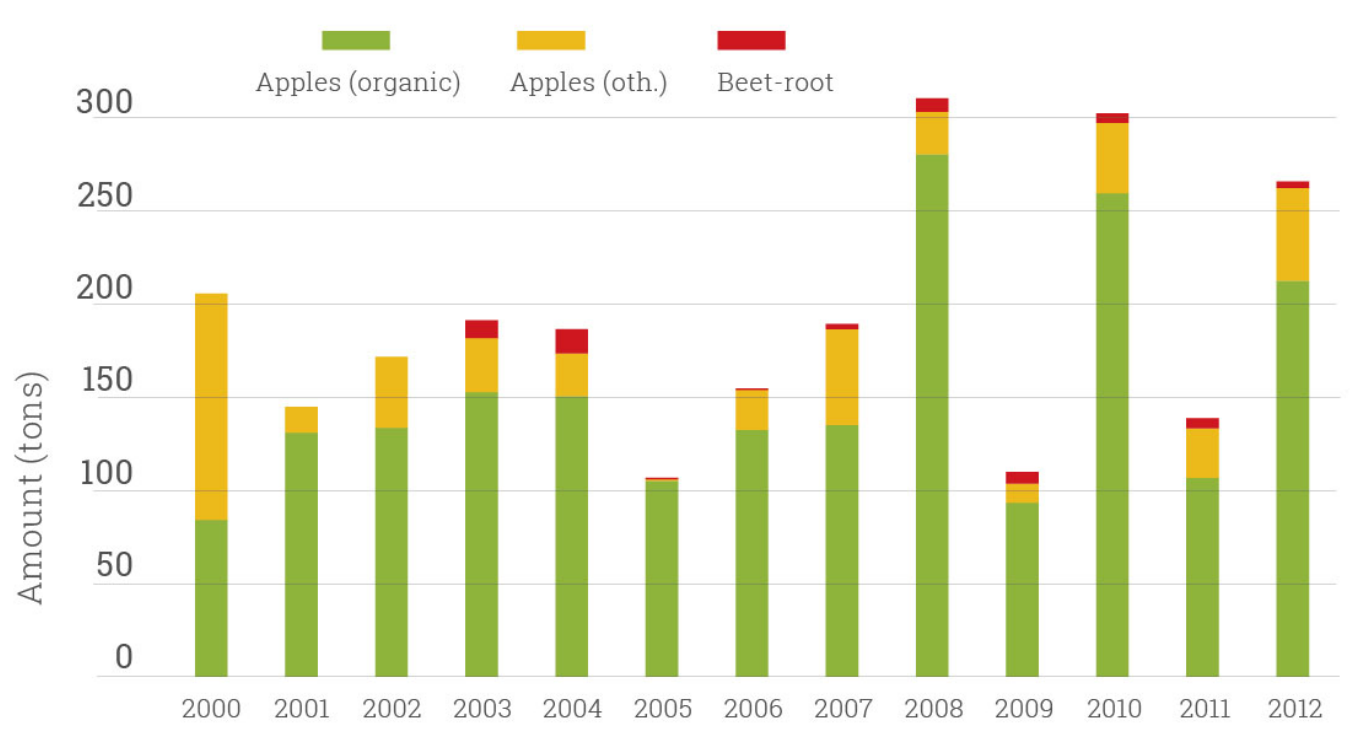

Figure 1: Raw materials processed in 2000-2012 (Labohý, 2013)

\section{Renewable energy}

A solar collector was installed on the roof of the cider house in 2001. It has a surface area of $36 \mathrm{~m}^{2}$ and it produces heat that is transferred to the $9 \mathrm{~m}^{3}$ heat storage tank insulated by $1 \mathrm{~m}$ of straw. There is an annual saving of $8.5 \mathrm{MWh}$ of electricity (needed otherwise to heat up water) due to the use of the solar collector (Labohý, 2013).

The photovoltaic plant has been in use since 2008. It consists of 40 panels on $64 \mathrm{~m}^{2}$ and its installed output is $8.8 \mathrm{~kW}$. The annual production of the plant is around $9000 \mathrm{kWh}$, which is almost the same as the annual consumption of the cider house. However, there is some seasonal variability. The consumption of electricity is bigger than the production during the fruit-making season in autumn; on the other hand, the production overtops the consumption during the summer, and the electricity is supplied to the grid. In $2012,22 \%$ of the electricity produced was consumed directly by the cider house and the plant generated $30 \%$ of the real cider house consumption (Labohý, 2013).

During the winter, the cider house uses heat from the municipal biomass heating plant. Therefore, almost all the energy consumed by the cider house comes from renewable resources.

\section{Landscape management}

Data from the LPIS public land use register demonstrate that the area of registered fruit orchards in the White Carpathians grew by a factor of more than 2.5 between 2003 and 2011. This significant increase was caused by the establishment of new orchards on the one hand, and by renewing the management of old orchards and re-registering them on the other hand. The area of organic fruit orchards exceeds the area of conventionally managed fruit orchards. The main impulses motivating this boom were subsidies for maintaining organic fruit orchards and subsidies for establishing intensively managed orchards. However, subsidies by themselves would not have motivated farmers, if there were no possibilities to sell certified organic fruit 
on the market. The cider house provides such an opportunity. The cider house also shares information about possible subsidies with potential orchard owners. Non-organic juice is also made from apples from local gardens and small orchards, which significantly contribute to landscape and biodiversity protection (Labohý, 2013).

\section{Waste}

The waste management of the cider house is the biggest problem of its current operation. After the collapse of the market for returnable bottles, which the cider house used from 2000 onwards, the cider house was forced to stop filling its ciders in returnable packaging when it bought the new bottling line. Therefore, the entire product range has been filled in non-returnable glass bottles since 2012. According to the majority of studies, they do have the biggest adverse environmental impact of any packaging material, but they also have a more closed life cycle than, e.g., PET bottles. It is therefore not entirely clear whether using non-returnable glass bottles is more environmentally friendly than the use of plastic bottles would be (Tichá, 2009). Unfortunately, however, there are not many ways of packaging in returnable sealable bottles. The possibilities for resolving the situation and their coupling with the market process requirements are being discussed, but the capital intensity of a progressive solution is entirely beyond the financing capacities of the cider house.

Organic water contamination is another adverse impact of the cider house operation. It turned out in the first year of operation of the Hostětín cider house that the high organic contamination of part of the wastewater (BOD up to $5000 \mathrm{mg} / \mathrm{l}$ of wastewater) exceeds the capacity of the reed bed plant, which was why part of the wastewater was intercepted in tanks and applied on local farmland as fertilising watering. The contamination has been reduced thanks to the installation of a new fruit press, and the wastewater is now primarily handled in a reed bed treatment plant (Labohý, 2013).

\section{Built capital}

\section{Funding}

Since the reconstruction and the operation of the cider house were initiated by the TBK, it had to be funded from multiple sources. The involvement of foreign experts of the Hëllef fir d'Natur foundation from Luxembourg made it possible to acquire the biggest grant contribution for the cider house construction from the Luxembourgish Ministries of the Environment and Foreign Affairs, and have a credit confirmed from the Luxembourgish ethical bank Alterfinanz. Thanks to its co-operation with other non-profit organisations and after extended efforts, the TBK eventually managed to reach out for grants, subsidies and favourable loans. The money for activities associated with the project planning and execution was thus acquired mostly from grants of Czech and international foundations. Contributions from sponsors, donors and volunteers' help in renovating the cider house and producing the cider in 1999-2001 also played an important role.

\section{Technology and investments}

The cider house succeeded in acquiring the complete technological equipment used for a very long time by a family cider house from a German cider and fruit wine manufacturer. Given the age of the component machines of the apple processing line (almost 30 years), however, it was necessary to overhaul all the equipment and put it back into operation. This was an appropriate task for the countryside artisans, who were just coming back home to the White Carpathians after years spent abroad. The acquisition of the 
equipment and the basic know-how, too, was the result of the co-operation with a Luxembourgish partner. The entire establishment of the cider house, involving the building renovation, the equipment preparation, overhauls and completion, the production process design, achieving compliance with the requirements for food production, and particularly organic farming production, and all the preparations for putting the products on the market, were done in the setting and under the leadership of the Veronica ČsOP local group. The cider house was commissioned in the 2000 season.

In 2007, a new storehouse was built, which is also an interesting structure from the energy point of view: it is insulated with straw bales. The building is capable of maintaining cold in summer and an adequate temperature in winter without requiring any external energy inputs. The storehouse is equipped with stainless steel storage tanks and a heat recovery pasteuriser, and a new press house with an automated conveyor belt fruit press was added to the storehouse. The remaining overhauled equipment was completely replaced before the autumn season of 2011 after 11 years of reuse. The current equipment is capable of processing up to three tonnes of apples in an hour, recovering juice from them with $70 \%$ efficiency. Unlike mass production, where the apple juice is concentrated after the pressing and then watered down with drinking water again while being bottled for the consumer, the apple cider from Hostětín is bottled without any watering or concentrating. A part of the juice that is not bottled directly during the pressing is stored for later use in the stainless steel tanks with a capacity of $10-13 \mathrm{~m}^{3}$. Before filling the tanks, the juice is pasteurised in a heat exchanger: it is heated up to $85^{\circ} \mathrm{C}$ and then cooled down with incoming cold juice (which is thus pre-warmed) to $25-30^{\circ} \mathrm{C}$. The heat recovery process saves up to $80 \%$ of energy. The juice is drawn from these storage tanks as needed later in the course of the year. Before bottling, the juice is pasteurised again.

The newly launched bottle filling and labelling process line makes it possible to fill product into multiple formats of glass bottles $(0.75 \mathrm{It}, 0.5 \mathrm{lt}$ and $0.2 \mathrm{It})$. In the last ten years, the cider house has invested a total of CZK 6.3 million in process equipment. Besides a production quality increase, energy savings are the common feature of these technology investments.

\section{Economic results}

\begin{tabular}{|l|l|l|l|l|l|l|l|l|l|l|}
\hline & $\mathbf{2 0 0 4}$ & $\mathbf{2 0 0 5}$ & $\mathbf{2 0 0 6}$ & $\mathbf{2 0 0 7}$ & $\mathbf{2 0 0 8}$ & $\mathbf{2 0 0 9}$ & $\mathbf{2 0 1 0}$ & $\mathbf{2 0 1 1}$ & $\mathbf{2 0 1 2}$ & Total \\
\hline Total costs & 2487 & 2102 & 1847 & 3364 & 3981 & 3492 & 4961 & 4916 & 5283 & \\
\hline $\begin{array}{l}\text { Total } \\
\text { revenues }\end{array}$ & 2585 & 2262 & 2201 & 3830 & 4078 & 4245 & 5472 & 5308 & 4961 & \\
\hline Profit & 98 & 160 & 354 & 466 & 97 & 753 & 511 & 393 & -322 & 2510 \\
\hline Profit Margin & $5 \%$ & $10 \%$ & $21 \%$ & $13 \%$ & $2 \%$ & $18 \%$ & $9 \%$ & $7 \%$ & $-6 \%$ & \\
\hline
\end{tabular}

Table 1: A summary of financial results in 2004-2012 (In thousands of CZK) (Labohý, 2013)

The financial results of the cider house are displayed in Table 1 . The project is profitable and its profit margin is within the norm for the business sector. In the years 2004 and 2005, results were affected by property transfers and the creation of a reserve fund for planned repairs to the press; the lower profits indicated in 2005 were also affected by an apple crop failure. The losses in 2012 were caused by a decrease in retail revenue and high depreciation, the results of investments from the preceding year (Labohý, 2013). 
The Hostětín cider house complies with the definition of a social enterprise, because it focuses on environmental and social objectives as well. Specifically, these include the preservation of the White Carpathian landscape character, support to organic farming, jobs, and a consumer paradigm shift. In addition, the ownership and management structure of the cider house meets the criteria for socially responsible business (J ohanisová, 2005).

\section{Human and social capital}

\section{Opinion of local inhabitants}

The project has gained support among the local population, because there have been the following benefits from their point of view:

- employment and economic benefits on a local scale;

- preservation of traditions and boost to self-confidence (pride in locally specific aspects);

- creation of numerous promotional materials about the region, spin-off activities, such as nature trails;

- increase in attractiveness of the region, influx of visitors, etc.

The Apple Festival, held annually in late September since 2001, is an important activity supporting local people, tradesmen, traditions, and fruit-growing. The festival is visited by 2000-4000 visitors each year. A tasting of fresh apple juice is combined with the possibility to buy local products and services. There is also an environmental and cultural programme. The festival relies on massive involvement of (not only) local volunteers.

\section{Employment}

The cider house employs one local inhabitant full-time and four other local inhabitants part-time. Along with the seasonal helpers, the cider house generates 3-4 converted employment positions. The numbers of both stable jobs and seasonal helpers have been increasing moderately over the years. Long-term unemployed are part of the seasonal workers (Labohý, 2013). However, the new, more automated equipment and the oscillating tendency of raw material purchases do not contribute to creation of new jobs at the cider house and might reverse the trend.

\section{Degree of localisation of the cider house expenditures}

The functioning of a local economy has been described by the local multiplier effect (LM3) indicator applied to the cider house accounting. When analysing the local expenditures of the cider house, Uhlířová (2008) calculated the local multiplier effect at LM3 for data for the accounting year 2006, and the limits of the area delineating the so-called local expenditures was set at $25 \mathrm{~km}$ from Hostětín. The LM3 was 1.63 in 2006. This means that every crown expended locally (i.e., spent within $25 \mathrm{~km}$ of Hostětín) brought the local economy an extra sixty-three rs. For a comparison with the trend in the following years, it was decided to set the proportion of local expenditures at LM2, that is, how much of its costs the cider house pays to suppliers within $25 \mathrm{~km}$. This LM2 indicator was 1.34 (meaning that $34 \%$ of the costs was spent within $25 \mathrm{~km}$, the rest going to suppliers farther away). However, this indicator has not been calculated again since the origin of this article. 
It is clear from the comparison of the results for 2007 and 2012 that the proportion of local costs has decreased significantly (Figure 2) according to the distance-based cumulated costs. The change in the packaging circulation contributes to this change the most: the new process equipment fills products in non-returnable bottles. The glass packaging is supplied by a company with a registered address in Dubí near Teplice. The proportion of the local costs expended within $25 \mathrm{~km}$ has thus decreased significantly (Labohý, 2013).

Analogously, the degree of localisation of the economic effect of the cider house can be expressed with the distance within which the company realises $80 \%$ of its costs. Whereas this was $138 \mathrm{~km}$ in 2007, this imaginary boundary had shifted almost twice as far, to 269 km, by 2012.

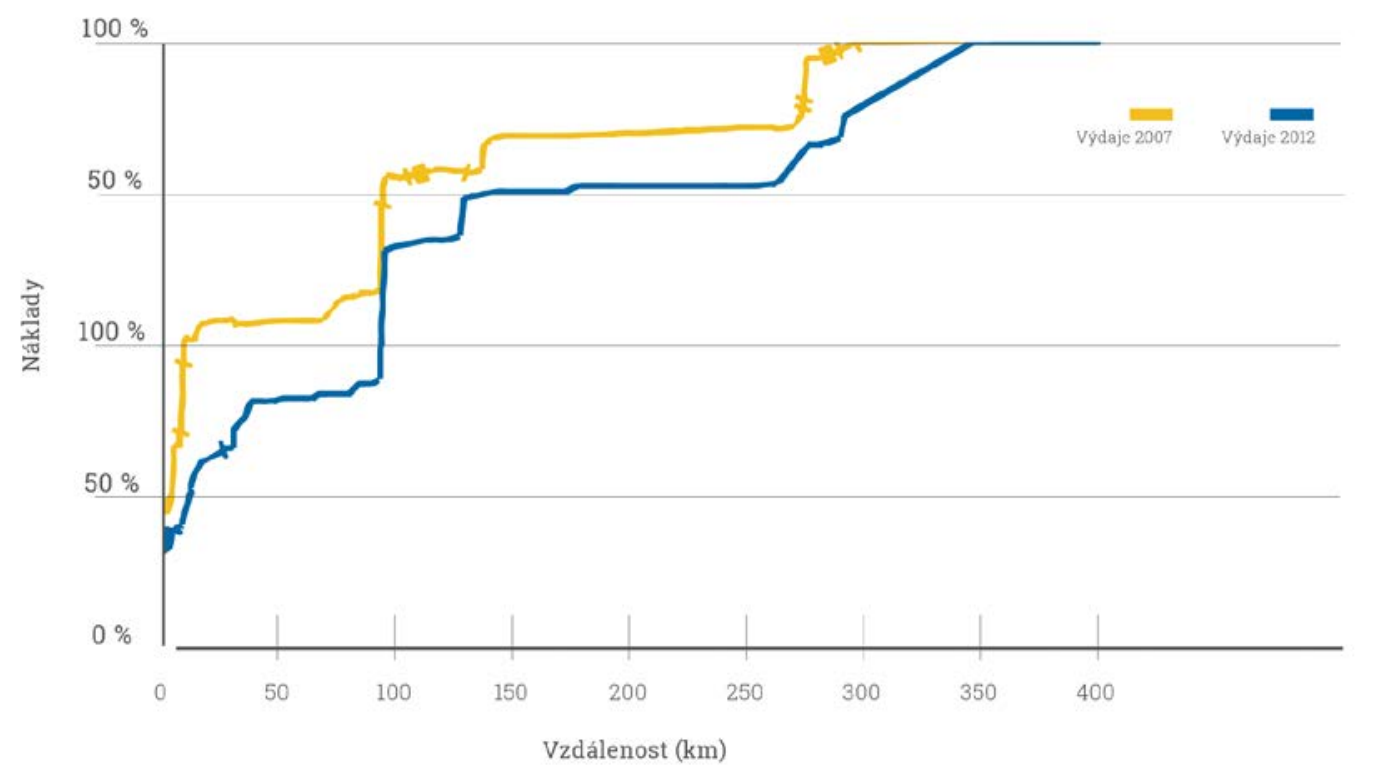

Figure 2: Cumulative cider house costs depending on distance (Labohý, 2013)

\section{Discussion}

The sustainability assessment suggests that the project itself leads towards sustainable development. However, there are several issues that could be discussed.

The true opinion of local people has not been assessed by a larger sociological research yet. Holub (2007) found that people were mostly satisfied with the ecological projects in Hostětín. One of his respondents mentioned the cider house as well: "We can hear the cider house, but I don't mind. It's an opportunity for local people to earn money." (Holub, 2007: 49) According to our observations, the cider house is the most popular project of all those implemented in Hostětín (as listed in the chapter Hostětín and its historical context). We suggest that it is the stress on the social and human capital (especially the employment of local people and the apple juice festival) that helps the popularity of the cider house.

Although the overall assessment suggests that the project as such promotes sustainable development, there are several important negative trends occurring. First of all, the degree of localisation of the cider house is diminishing and therefore more money is floating out of the region. Secondly, the automation of the cider house may shrink the number of local employees; and thirdly, the switch from refundable bottles to non-refundable 
ones increases the waste production. Those trends represent mostly the external pressure from the society and the environmental policy of the state. Hence, they might be out of control of the small enterprise. Similar problems might be found in other social enterprises in the Czech Republic.

The set of indicators developed for the purpose of this article is largely context- based and it cannot be simply transferred to other projects. A use of standardised research methods would enable us to compare the results with other similar projects and benchmark the sustainability progress. On the other hand, we believe that both understanding and promoting sustainability must come from grassroots and therefore we chose the locally grounded indicators.

Follow-up research would also be needed to interconnect the experience from the Hostětín projects with experience from other small-scale sustainability projects in the Czech Republic, especially regarding projects implemented as part of the Local Agenda 21 movement.

More research is needed to develop tools for assessment of other projects in Hostětín as well. It would be of special interest to make an analysis using the concepts of knowledge communities (Henry and Pinch, 2000) and learning regions (MacKinnon, 2002) and comparing them to Hostětín's sustainability experience.

\section{Conclusions}

The indicators outlined in the Methods section were used to assess the sustainability of the Hostětín cider house project as well as the initial goals of the project to "support the preservation of traditional fruit-growing in the White Carpathians by means of fruit processing and product marketing". We have described that the existence of the cider house contributes to the preservation of the White Carpathian apple varieties, which thus remain preserved for future generations. The cider house uses local resources and renewable energy, it guarantees good purchase prices, and the owners are thus well motivated to take care of tall-growing fruit trees again. The provision of 3-4 converted employment positions is also important. The cider house thus creates job opportunities even for citizens who find it more difficult to get a job.

The progress of the cider house towards sustainable development happens through:

- support and promotion of organic farming;

- processing of local fruit production;

- use of renewable energy sources;

- durable economic results;

- support to the original landscape character and diversity;

- $\quad$ support to local economy and creating job opportunities;

- possibility to disseminate the experience. 
In this case, the sustainability assessment using the community indicators developed suggests that the initial goals have been met and that the project itself leads towards sustainable development.

The success of the cider house has been achieved thanks to a systemic process focused on meeting of goals set by the non-governmental organisation. The co-operation with partner organisations abroad (transfer of know-how, experience, moral support, etc.), the goodwill of sponsors inclined towards environmental innovation, the entry of the Veronica Foundation and the support of local citizens were also crucial to the project success.

Although the establishment of the cider house was initiated by a non-profit organisation, it has grown over time to a self-sufficient entity interlinked with the local economy. However, it has required the non-governmental organisation (Veronica ČsOP local chapter) to invest lots of energy in designing project proposals, elaborating, submitting and organising them as well as the project management.

The cider house project was created intentionally as reproducible. Taking into account local conditions, the project can also be implemented in other places both inside and outside the Czech Republic.

\section{Acknowledgments}

The article was written as a part of the "Varieties of Environmental Friendly Lifestyles 2: A Pathway to a City" project of the Masaryk University (0769/2013). The research was supported by the MOSUR project (OP VK CZ1.07/2.4.00/17.0130) funded by the European Social Fund in the Czech Republic - http://mosur.czp.cuni.cz.

\section{References}

- AGENDA 21: Earth Summit, The United Nations Programme of Action from Rio (1993) : UN.

- Bell, S., \& Morse, S. (2008). Sustainability indicators: Measuring the immeasurable? : Earthscan.

- Brundtland, G., \&et.al., (1987). Our common future: The world commission on environment and development.

- Costanza, R., \& Daly, H. E. (1992). Natural capital and sustainable development. Conservation biology, 6(1), 37-46. http://dx.doi.org/10.1046/j.15231739.1992.610037.x

- Elliott, J. A. (2012). An introduction to sustainable development. London: Routledge.

- Goodwin, N. R. (2003). Useful concepts for sustainable development. Tufts University.

- Hák, T.; Kovanda, J. (2006) Co, jak a pro koho-aneb kritéria tvorby indikátorů environmentální udržitelnosti. [What, Why and For Whom - Criteria for Creating Environmental Indicators of Sustainability] Proceedings of the Conference Doprava, zdraví a životní prostředí, 2006. 
- Harger, J. R. E., \&Meyer, F. M. (1996). Definition of indicators for environmentally sustainable development. Chemosphere, 33(9), 1749-1775.

http://dx.doi.org/10.1016/0045-6535(96)00194-4

- Henry, N., \&Pinch, S. (2000). Spatialising knowledge: placing the knowledge community of Motor Sport Valley. Geoforum, 31(2), 191-208. http://dx. doi.org/10.1016/S0016-7185(99)00038-X

- Holub, P. (2007). Obnovitelné zdroje energie, decentralizace společnosti a komunitní život. [Renewable Energy Resources, Society Decentralisation, and Community Life]. Brno: Masarykova univerita. Retrieved from http://is.muni.cz/th/22769/fss_m_b1/

- Johanisova, Nadia, (2005). Living in the Cracks: A Look at Rural Society Enterprises in Britain and the Czech Republic. Dublin: FEASTA. Retrieved from http://www.feasta.org/documents/living_in_the_cracks/

- Kates, R. W., Clark, W. C., Corell, R., Hall, J. M., Jaeger, C. C., Lowe, I., . . . Svedlin, U. (2001). Sustainability science in Local Communities. Science, 292(5517), 641-642. Retrieved from http://www. scholaruniverse.com/ncbilinkout?id=11330321 pmid: $11330321 \mathrm{http}: / / \mathrm{dx}$. doi.org/10.1126/science. 1059386

- Kovanda, J., Hak, T., \& Janacek, J. (2008). Economy-wide material flow indicators in the Czech Republic: trends, decoupling analysis and uncertainties. International J ournal of Environment and Pollution, 35(1), 25-41.

http://dx. doi.org/10.1504/IJEP.2008.021129

- Kutáček, S. (2007). Penězům na stopě (měření vašeho dopadu na místní ekonomiku pomocí LM3). Brno: Trast pro ekonomiku a společnost. Retrieved from http://www. thinktank.cz/index.php?id=374

- Labohý, J. (2013). Co přinesly projekty v Hostětíně? 20 let na cestě k energetické soběstačnosti. 3rd modified ed. Brno: Ekologický Institut Veronica. Retrieved from http://hostetin.veronica.cz/studie

- Lafferty, W. M., \& Eckerberg, K. (2013). From the Earth Summit to Local Agenda 21: Working towards sustainable development. Routledge.

- MacKinnon, D., Cumbers, A., \&Chapman, K. (2002). Learning, innovation and regional development. Progress in Human Geography, 26(3), 293-311. http://dx. doi.org/10.1191/0309132502ph371ra

- Mastalka, M. (2009). Územně promítnutelné indikátory udržitelného rozvoje. [Locally Used Sustainable Development Indicators]. Brno: Vysoké učení technické $v$ Brně.

- Mascarenhas, R., Guiote, V., Agro, J., \&Henrique, M. (2010). The role of common local indicators in regional sustainability assessment. Ecological Indicators, 10(3), 646-656. http://dx.doi.org/10.1016/j. ecolind.2009.11.003

- Meadows, D. H. (1998). Indicators and information systems for sustainable development. Hartland: Sustainability Institute. 
- Moldan, B., Hák, T., \& Kolářová, H. (2002) K udržitelnému rozvoji České republiky: Vytváření podmínek. [Regarding the Sustainable Development: Preparing Conditions]. Praha: Univerzita Karlova v Praze, Centrum pro otázky životního prostředí.

- Moldan, B. (1996). Indikátory trvale udržitelného rozvoje. [Sustainable Development Indicators]. Vysoka Skola Banska - Technicka Univerzita.

- Ness, B., Urbel-Piirsalu, E., Anderberg, S., \& Olsson, L. (2007). Categorising tools for sustainability assessment. Ecological Economics, 60(3), 498-508.

http://dx.doi.org/10.1016/j.ecolecon.2006.07.023

- OECD, (1993). Core Set of Indicators for Environmental Performance Reviews: A synthesis report by the Group on the State of the Environment. Organisation for Economic Co-operation and Development, Number 83. Paris: OECD. Retrieved from http://enrin.grida.no/htmls/armenia/soe2000/eng/oecdind.pdf

- Pope, J., David Annandale, Angus Morrison-Saunders. Conceptualising sustainability assessment. Environmental Impact Assessment Review, 24(6), 595616. http://dx. doi.org/10.1016/j.eiar.2004.03.001

- Pohekar, S. D., \& Ramachandran, M. (2004). Application of multi-criteria decision making to sustainable energy planning-A review. Renewable and Sustainable Energy Reviews, 8(4), 365-381. http://dx.doi.org/10.1016/j.rser.2003.12.007

- Sacks, J. (2002). The money trail. Measuring your impact on the local economy using LM3. London: New Economics Foundation and The Countryside Agency.

- Singh, R. K., Murty, H. R., Gupta, S. K., \& Dikshit, A. K. . An overview of sustainability assessment methodologies. Ecological Indicators, 9(2), 189-212. http://dx.doi.org/10.1016/j.ecolind.2008.05.011

- Študent, J., \& Hyršlová, J., Vaněček, V., (2005). Udržitelný rozvoj a podnikání. [Sustainable development and entrepreneurship] (Environmentální reporting. Hodnocení udržitelného rozvoje a Environmentální účetnictví). Praha: CEMCPríručka pro odborníky a vedení organizací. Praha: CEMC.

- Tarzia, V. (2003). European Common Indicators: Towards a local sustainability profile. Milano: Ambiente Italia Research Institute.

- Tetera, V. (2006). Ovoce Bílých Karpat. Základní organizace ČsOP Bílé Karpaty ve Veselí nad Moravou.

- Tichá, M. (2009). Porovnání environmentálních dopadů nápojových obalů v ČR metodou LCA. Retrieved from http://lca-cz.cz/projekt-Ica/vystupy.html

- Uhlírová, J. (2008). Co přinesly projekty v Hostětíně?: Analýza modelových projektů udržitelného rozvoje. [What are the outcomes of the projects in Hostětín? Analysis of model projects for sustainable development]. Trast pro ekonomiku a společnost.

- Valentin, A., \& Spangenberg, J. H. . A guide to community sustainability indicators. Environmental Impact Assessment Review, 20(3), 381-392. http://dx. doi.org/10.1016/S0195-9255(00)00049-4 
- Weinzettel, J., \& Kovanda, J. (2009). Assessing socioeconomic metabolism through hybrid life cycle assessment. J ournal of Industrial Ecology, 13(4), 607-621. http://dx.doi.org/10.1111/j.1530-9290.2009.00144.x

- ZPRÁVA o stavu životního prostředí České republiky v roce 1993 [Report on the State of the Environment in the Czech Republic in 1993] (1993). Praha : MŽP ČR.

Mgr. J an Labohý, Department of Environmental Studies, Faculty of Social Studies, Masaryk University

RNDr. Yvonna Gaillyová, CSc., Veronica Ecological Institute, ČsoP

Mgr. Radim Machů, Tradice Bílých Karpat civic association; Hostětín Cider house 